\title{
High Iron-Sequestrating Bifidobacteria Inhibit Enteropathogen Growth and Adhesion to Intestinal Epithelial Cells In vitro
}

\author{
Pamela Vazquez-Gutierrez, Tomas de Wouters, Julia Werder, Christophe Chassard and \\ Christophe Lacroix*
}

Laboratory of Food Biotechnology, Institute of Food, Nutrition and Health, ETH Zurich, Zürich, Switzerland

OPEN ACCESS

Edited by:

Marco Ventura,

University of Parma, Italy

Reviewed by:

Silvia Arboleya Montes, Teagasc and APC Microbiome

Institute, Ireland

Lorena Ruiz,

Universidad Complutense de Madrid,

Spain

*Correspondence:

Christophe Lacroix

christophe.lacroix@hest.ethz.ch

Specialty section:

This article was submitted to

Microbial Symbioses,

a section of the journal

Frontiers in Microbiology

Received: 06 July 2016 Accepted: 06 September 2016 Published: 22 September 2016

Citation:

Vazquez-Gutierrez $P$, de Wouters $T$, Werder J, Chassard C and Lacroix C

(2016) High Iron-Sequestrating Bifidobacteria Inhibit Enteropathogen Growth and Adhesion to Intestinal Epithelial Cells In vitro.

Front. Microbiol. 7:1480.

doi: 10.3389/fmicb.2016.01480
The gut microbiota plays an important role in host health, in particular by its barrier effect and competition with exogenous pathogenic bacteria. In the present study, the competition of Bifidobacterium pseudolongum PV8-2 (Bp PV8-2) and Bifidobacterium kashiwanohense PV20-2 (Bk PV20-2), isolated from anemic infant gut microbiota and selected for their high iron sequestration properties, was investigated against Salmonella Typhimurium (S. Typhi) and Escherichia coli O157:H45 (EHEC) by using co-culture tests and assays with intestinal cell lines. Single and co-cultures were carried out anaerobically in chemically semi-defined low iron (1.5 $\mu \mathrm{M} \mathrm{Fe}$ ) medium (CSDLIM) without and with added ferrous iron (30 $\mu \mathrm{M} \mathrm{Fe}$ ). Surface properties of the tested strains were measured by bacterial adhesion to solvent xylene, chloroform, ethyl acetate, and to extracellular matrix molecules, mucus II, collagen I, fibrinogen, fibronectin. HT29-MTX mucussecreting intestinal cell cultures were used to study bifidobacteria competition, inhibition and displacement of the enteropathogens. During co-cultures in CSDLIM we observed strain-dependent inhibition of bifidobacterial strains on enteropathogens, independent of $\mathrm{pH}$, organic acid production and supplemented iron. Bp PV8-2 significantly $(P<0.05)$ inhibited S. Typhi N15 and EHEC after $24 \mathrm{~h}$ compared to single culture growth. In contrast Bk PV2O-2 showed less inhibition on S. Typhi N15 than Bp PV8-2, and no inhibition on EHEC. Affinity for intestinal cell surface glycoproteins was strain-specific, with high affinity of Bp PV8-2 for mucin and Bk PV2O-2 for fibronectin. Bk PV20-2 showed high adhesion potential $(15.6 \pm 6.0 \%)$ to HT29-MTX cell layer compared to Bp PV8-2 (1.4 \pm 0.4\%). In competition, inhibition and displacement tests, Bp PV8-2 significantly $(P<0.05)$ reduced $S$. Typhi N15 and EHEC adhesion, while Bk PV202 was only active on S. Typhi N15 adhesion. To conclude, bifidobacterial strains selected for their high iron binding properties inhibited S. Typhi N15 and EHEC in co-culture experiments and efficiently competed with the enteropathogens on mucusproducing HT29-MTX cell lines. Further studies in complex gut ecosystems should explore host protection effects of Bp PV8-2 and Bk PV20-2 mediated by nutritional immunity mechanism associated with iron-binding.

Keywords: iron sequestration, bifidobacteria, enteropathogens, inhibition, intestinal cell, adhesion 


\section{INTRODUCTION}

Bifidobacteria are among the first commensal anaerobic bacteria that reach high levels in the infant gut within the first week of life, representing up to $50-80 \%$ of the gut bacteria (Jost et al., 2012; Turroni et al., 2012). The establishment of bifidobacteria in the gut has been associated with a broad range of beneficial effects on host health, such as modulation of intestinal microbiota composition, prevention of infection and immune-modulation (Broekaert and Walker, 2006; Yatsunenko et al., 2012). Inhibition of pathogens in the gut by bifidobacteria might be due to production of inhibitory substances, inhibition of epithelial and mucosal invasion of pathogens, competition for limited nutrients and/or the stimulation of mucosal immunity (Marco et al., 2006; Turroni et al., 2014). Potential inhibition mechanisms include the production of short-chain fatty acids and subsequent local $\mathrm{pH}$ decrease (Fukuda et al., 2011), or other antimicrobial compounds such as bacteriocins (Cheikhyoussef et al., 2008; Dobson et al., 2012; Martinez et al., 2013). Bifidobacteria can also compete with pathogens for adhesion to intestinal epithelial sites and nutrients, enhancing resistance to colonization of pathogenic bacteria (Collado et al., 2007; Aires et al., 2010).

The gut microbiota is constantly challenged by different stress factors, including enteropathogens, such as Salmonella and Escherichia coli O157:H45 (EHEC; Wardlaw et al., 2010). Pathogenesis of Salmonella requires its adhesion to host cell surfaces followed by invasion of intestinal epithelial cells, leading to systemic spreading (Sansonetti, 2004; Haraga et al., 2008; Santos et al., 2009). EHEC pathophysiology is attributed to the effects of shiga toxins encoded on the pO157 plasmid, survival to harsh conditions and the formation of attachingand-effacing lesions on epithelial cells (Muller et al., 2009; Melton-Celsa et al., 2012; Thiennimitr et al., 2012). To inhibit pathogen infection in the gut, commensal intestinal microorganisms such as bifidobacteria, should be able to compete for corresponding niches. Bifidobacteria have been reported to occupy attachment sites, therefore preventing pathogen invasion and translocation (Bernet et al., 1994; Goto and Kiyono, 2012). The inhibitory activity and mechanisms of bifidobacteria against enteropathogens have been investigated by microbe-microbe and cell-microbe interaction models (Collado et al., 2007).

Different intestinal epithelial cell lines exhibiting specific characteristics and functions of the gut epithelium are used to study host-pathogen interactions. HT29-MTX cell line is a mucus-secreting clone of the HT-29 intestinal epithelial cell line suitable for mimicking the mucosal surface of the gut epithelium, which acts as the first line of interaction between the microbiota and its host (Lesuffleur et al., 1990; Gagnon et al., 2013). The intestinal mucus layer functions as a physical barrier, separating the epithelium from the bacterial load in the intestinal lumen. Mucus is also an important nutrient source for gut microbes and promotes selective adhesion of gut bacteria to the intestinal mucus layer. Interactions with the intestinal mucus layer is a property of commensal gut bacteria that can enhance the barrier function of the intestinal epithelium by limiting access of pathogens to this specific niche. The adherence to intestinal epithelial cells is therefore an important characteristic for beneficial gut bacteria, enhancing persistence in the gut, pathogen exclusion effects and specific bacterial and hostimmune system interactions (Izquierdo et al., 2008; Bron et al., 2012).

The ability of bacteria to establish in the intestine is heavily dependent on competition for nutrients (Andrews et al., 2003). For example iron is an essential micronutrient for growth, proliferation, and persistence for most gut bacteria, including bifidobacteria and enteropathogens (Turroni et al., 2014). Pathogens such as S. Typhi and EHEC are known to possess efficient iron sequestration mechanisms that contribute to their pathogenicity and competitiveness in the gut (Berkley et al., 2005; Wardlaw et al., 2010; Cassat and Skaar, 2013; Monack and Hultgren, 2013; Winter et al., 2013). These systems have been directly linked to the ability of strains with high iron sequestration properties to establish efficiently in the gut (Weinberg, 2009; Kortman et al., 2012). In a previous study we reported isolation of 56 bifidobacterial strains from stools of breast fed, iron-deficient and anemic Kenyan infants (VazquezGutierrez et al., 2015c). Isolated strains were characterized and compared to public culture collection strains. Bifidobacterium kashiwanohense PV20-2 (Bk PV20-2) and Bifidobacterium pseudolongum PV8-2 (Bp PV8-2) were selected for their high siderophore activity (iron-chelating molecules) and iron internalization. Analysis of the complete genome allowed to identify ferrous and specific ferric iron operons in both strains (Vazquez-Gutierrez et al., 2015a,b,c). Furthermore, a ferrous iron-binding protein and other proteins with adhesive properties were identified in the extracellular fraction of Bk PV20-2 together with. In the extracellular proteome of Bp PV8-2 a ferric ironbinding protein belonging to the ferric iron transport operon was shown. In the present study, the inhibitory activity of Bp PV8-2 and Bk PV20-2 was investigated during co-cultures with $S$. Typhi $\mathrm{N} 15$ and EHEC as a function of iron concentrations (1.5 and $30 \mu \mathrm{M})$ ). Surface properties were tested by bacterial adhesion to solvent (BATS) and extracellular matrix molecules (ECMs) and the competition for epithelial binding sites was studied in HT29-MTX intestinal cellular model.

\section{MATERIALS AND METHODS}

\section{Bacterial Strains and Growth Conditions}

Bifidobacterium pseudolongum DSMZ20099 (Bp DSMZ20099) and B. kashiwanohense DSMZ21854 (Bk DSMZ21854) were obtained from the German collection of microorganisms (DSMZ; Leibniz, Germany). B. pseudolongum PV8-2 (Bp PV8-2) and B. kashiwanohense PV20-2 (Bk PV20-2), were obtained from the culture collection of the Laboratory of Food Biotechnology (ETH Zurich, Switzerland). Salmonella enterica ssp. enterica serovar Typhimurium N15 (S. Typhi N15) a clinical isolate obtained from the National Centre for Enteropathogenic Bacteria and Listeria (NENT, University of Zurich, Switzerland) and E. coli O157:H45 (EHEC) were kindly provided by Prof. Roger Stephan. Bifidobacteria were routinely cultured in de Man, Rogosa, and Sharpe (MRS) broth (Biolife, Italy) supplemented with 0.05\% of L-cysteine hydrochloride monohydrate (cys; Sigma-Aldrich, 
Switzerland). Enteropathogens were cultured in Luria-Bertani (LB) broth (Becton Dickinson, Switzerland) unless otherwise specified. Cells suspensions and serial dilutions were carried out in peptone water at $\mathrm{pH} 6.5$, containing $1.5 \mathrm{~g} / \mathrm{L}$ peptone water (CDH Bioscience, India) and $0.6 \mathrm{~g} / \mathrm{L}$ cys (peptone-cys). Bifidobacterial viable cell counts were determined on MRS-cys agar (Becton Dickinson, Switzerland) plates, incubated for $72 \mathrm{~h}$ under anaerobiosis in anaerobic jars. S. Typhi and EHEC enumeration was done in Mac-Conkey agar (Oxoid, Switzerland) incubated $24 \mathrm{~h}$ at $37^{\circ} \mathrm{C}$. A chemically semidefined low iron medium (CSDLIM) with a low iron concentration of $1.5 \mu \mathrm{M}$ was used for co-culture interaction assays. The CSDLIM medium was previously used to test siderophore production with the CAS assay (Vazquez-Gutierrez et al., 2015c). Iron supplementation of the CSDLIM medium was achieved by adding $30 \mu \mathrm{M}$ of ferrous iron (Sigma-Aldrich, Switzerland), corresponding to the iron concentration previously reported to increase Salmonella and EHEC pathogenicity (Cernat and Scott, 2012; Kortman et al., 2012). Iron concentration in CSDLIM was measured by graphic furnace atomic absorption spectrometry (VazquezGutierrez et al., 2015c).

\section{Inhibitory Activity of $B$. pseudolongum PV8-2 and B. kashiwanohense PV20-2 during Co-cultures with Enteropathogens}

Growth interactions of bifidobacteria and enteropathogens were investigated in CSDLIM with and without added ferrous iron as follow. The corresponding strains were first cultured twice at $37^{\circ} \mathrm{C}$ in MRS-cys for $24 \mathrm{~h}$ and LB broth for $12 \mathrm{~h}$, respectively. Bacterial cells were harvested by centrifugation (Biofuge Primo, Heraeus, Switzerland) at $4^{\circ} \mathrm{C}, 16,000 \times g$ for $10 \mathrm{~min}$. The supernatant was discarded and the pellet was resuspended in peptone-cys water to an $\mathrm{OD}_{600 \mathrm{~nm}}$ of 1.0. Hungate tubes containing $10 \mathrm{~mL}$ of CSDLIM with headspace filled with $\mathrm{CO}_{2}$ were inoculated with $\log _{10} 6.5 \pm 0.05 \mathrm{CFU} / \mathrm{mL}$ Bp PV8-2, $\log _{10}$ $6.6 \pm 0.13 \mathrm{CFU} / \mathrm{mL}$ Bk PV20-2, $\log _{10} 5.5 \pm 0.06$ CFU S. Typhi $\mathrm{N} 15 / \mathrm{mL}$ and $\log _{10} 5.4 \pm 0.15 \mathrm{CFU} / \mathrm{mL}$ EHEC for both mono- and co-cultures. Hungate tubes were incubated at $37^{\circ} \mathrm{C}$ for $24 \mathrm{~h}$ and samples were taken at 0,12 , and $24 \mathrm{~h}$ from the same tube through septum for absorbance determination at $\mathrm{OD}_{600 \mathrm{~nm}}$ (Biowave, CO8000, Biochrom, Ltd, England), $\mathrm{pH}$ and viable cell counts. Short chain fatty acid (SCFA) concentrations were measured by high performance liquid chromatography (HPLC; Thermo Fisher Scientific, Switzerland) as previously described (Cleusix et al., 2008). Briefly, $1 \mathrm{~mL}$ culture samples were centrifuged for $12 \mathrm{~min}$ at $10,000 \times g$ and $4^{\circ} \mathrm{C}$. Supernatant was filtered with a $0.45 \mu \mathrm{m}$ nylon membrane (Infochroma AG, Switzerland) directly into HPLC vials. Analysis was performed at a flow rate of $0.4 \mathrm{~mL} / \mathrm{min}$ with $10 \mathrm{mM}$ sulphuric acid as eluent with an injection volume of $20 \mu \mathrm{L}$. Mean metabolite concentrations were expressed in millimolar ( $\mathrm{mM})$. Three independent repetitions of mono- and co-cultures in CSDLIM with and without ferrous iron supplementation ( $30 \mu \mathrm{M}$ ferrous iron) were carried out.

To test the effects of $\mathrm{pH}$ decrease and SCFA on enteropathogens growth inhibition, S. Typhi N15 and EHEC were incubated at $37^{\circ} \mathrm{C}$ for $12 \mathrm{~h}$, at $\mathrm{pH} 4.5$ ( $\mathrm{pH}$ measured at the end of co-cultures) and SCFA concentrations where enteropathogen counts began to decrease during co-cultures. After centrifugation at $4^{\circ} \mathrm{C}$ and $16,000 \times g$ for $10 \mathrm{~min}$, cell pellets were suspended in peptone-cys water and adjusted to $\mathrm{OD}_{600 \mathrm{~nm}}$ 1.0. Then hungate tubes containing $10 \mathrm{~mL}$ of CSDLIM pH 4.5, $7 \mathrm{mM}$ lactate and $13 \mathrm{mM}$ acetate, were inoculated with $\log _{10}$ $5.4 \pm 0.06 \mathrm{CFU} / \mathrm{mL}$ S. Typhi N15 and $\log _{10} 5.3 \pm 0.13 \mathrm{CFU} / \mathrm{mL}$ EHEC, which were the viable cell counts reached in co-cultures after $12 \mathrm{~h}$ incubation. Hungate tubes were incubated for $24 \mathrm{~h}$ at $37^{\circ} \mathrm{C}$ and $1 \mathrm{~mL}$ sample was taken every $4 \mathrm{~h}$ to determine $\mathrm{pH}$, absorbance at $600 \mathrm{~nm}$ and viable cell counts. The experiment was performed in three independent replicates in CSDLIM with and without ferrous iron supplementation.

\section{Surface Properties of Bifidobacterial Strains}

The BATS assay was used to investigate cell surface properties of bifidobacterial strains according to Xu et al. (2009), with slight modifications. Surface hydrophobicity, electron donor and acceptor properties were determined based on the affinity of bifidobacteria to xylene (apolar solvent), chloroform (polar acidic solvent) and ethyl-acetate (polar basic solvent). Bifidobacteria were cultured in MRS-cys and CDSLIM as described above. Briefly, cell pellets were re-suspended in phosphate-buffered saline (PBS), $\mathrm{pH} 7.3$ to an $\mathrm{OD}_{600 \mathrm{~nm}}$ of 1.0. A volume of $3 \mathrm{~mL}$ of cell suspension was mixed with $1 \mathrm{~mL}$ of either xylene, chloroform (electron-acceptor), or ethyl-acetate (electron-donor; Sigma-Aldrich, Switzerland). The mixture was vortexed for $1 \mathrm{~min}$ and allowed to stand for $5 \mathrm{~min}$ to allow separation into two distinct phases. Then $1 \mathrm{~mL}$ of the aqueous phase was carefully collected with a pipette and $\mathrm{OD}_{600 \mathrm{~nm}}$ was measured using a UV-Visible spectrophotometer CARY 1Bio (Varian, Switzerland). The decrease in absorbance of the aqueous phase after contact with solvent was used as a measure of the cell surface hydrophobicity or electron-donor/electron-acceptor interaction. BATS was expressed by BATS $(\%)=\left(1-\mathrm{A}_{5} \min / \mathrm{A}_{0} \min \right) \times 100$, where $A_{0}$ min and $A_{5}$ min were the absorbance before and after extraction with the solvents, respectively (Xu et al., 2009). Three independent replicates of the experiment were carried out.

\section{Adhesion to Different Intestinal Cell Surface Molecules}

The adhesion affinities of bacteria to the ECMs of intestinal epithelial cells were tested as described previously (Sillanpaa et al., 2008), with slight modifications. Briefly, a solution of type II mucus (Sigma-Aldrich, Switzerland) at $50 \mu \mathrm{g} / \mathrm{mL}$ was prepared in Tris- $\mathrm{HCl}(0.1 \mathrm{M}, \mathrm{pH}$ 8). Collagen I, fibrinogen and fibronectin (all from Sigma-Aldrich, Switzerland) were resuspended at $10 \mu \mathrm{g} / \mathrm{mL}$ in PBS (Gibco, Switzerland), $\mathrm{pH}$ 7.5. Bovine serum albumin (BSA; Sigma-Aldrich, Switzerland) was resuspended at $50 \mu \mathrm{g} / \mathrm{mL}$ in Tris- $\mathrm{HCl}$ and used as control for unspecific adhesion to protein surfaces. $100 \mu \mathrm{L}$ of each suspension were applied to wells of a MaxiSorp ${ }^{\mathrm{TM}}$ 96-well microtiter plate (Nunc, Switzerland) and kept overnight at $4^{\circ} \mathrm{C}$ for adsorption. After removal of the liquid, adsorbed molecules were fixed for $10 \mathrm{~min}$ 
at $65^{\circ} \mathrm{C}$ and subsequently blocked with $100 \mu \mathrm{L}$ PBS $1 \%$ tween 20 per well for $1 \mathrm{~h}$ at $37^{\circ} \mathrm{C}$. Before application of bacteria, plates were washed three times with $100 \mu \mathrm{L}$ PBS $0.005 \%$ tween 20 to remove unbound ECM, filled with $100 \mu \mathrm{L}$ PBS and used within 24 h storage at $4^{\circ} \mathrm{C}$.

Bifidobacteria and enteropathogen strains were first cultured in MRSc or LB media, respectively, then transferred and grown in CDLSIM, as presented above. Briefly, cell pellets $\left(24^{\circ} \mathrm{C}\right.$, $16,000 \times g$ during $10 \mathrm{~min}$ ) were re-suspended in $\mathrm{PBS}$ at $\mathrm{pH} 5.5$ and $\mathrm{pH} 7.5$ to $\mathrm{OD}_{600 \mathrm{~nm}}$ of 1.0. $100 \mu \mathrm{l}$ of bacterial suspension was applied in triplicates to coated plates and incubated for $1 \mathrm{~h}$ at $37^{\circ} \mathrm{C}$ to induce bacterial adhesion. Wells were washed three times with $100 \mu \mathrm{L}$ PBS $0.005 \%$ Tween 20 to remove unattached bacteria and dried for $10 \mathrm{~min}$ at $65^{\circ} \mathrm{C}$. Adhered bacteria were stained with $100 \mu \mathrm{L}$ crystal violet $(1 \mathrm{mg} / \mathrm{mL}$, Sigma-Aldrich, Switzerland) per well for $45 \mathrm{~min}$ at room temperature. Crystal violet retained by fixed bacteria after three washing steps with $100 \mu \mathrm{L}$ PBS was resolubilized in $100 \mu \mathrm{L}$ citrate buffer $(50 \mathrm{mM}$; $\mathrm{pH}$ 4) under continuous shaking at $37^{\circ} \mathrm{C}$ for $1 \mathrm{~h}$. Absorbance of solubilized crystal violet was measured at $\mathrm{OD}_{595} \mathrm{~nm}$ using a Powerwave XS spectrophotometer (Bio Tek, Switzerland). The experiment was carried out in three independent replicates.

\section{In vitro Antagonism of Bifidobacteria against Pathogen Adhesion to HT29-MTX Cells}

The mucus-secreting intestinal epithelial cell line HT29-MTX was used to investigate adhesion properties of bifidobacteria and enteropathogens, as described previously with slight modifications (Gagnon et al., 2013). Briefly, HT29-MTX cells were seeded in 24-well tissue culture plates (Bioswisstec, Switzerland) at a concentration of $4 \times 10^{4}$ cells/well, and grown in Dulbecco's Modified Eagle Medium (DMEM; SigmaAldrich, Switzerland) supplemented with 20\% fetal bovine serum (Invitrogen, Switzerland), 1\% penicillin/streptomycin (Life Technologies, Switzerland), and 1\% non-essential amino acids (Life Technologies, Switzerland), at $37^{\circ} \mathrm{C}$ and $10 \% \mathrm{CO}_{2}$ in a humidified incubator (RB150, Revco, Switzerland). Culture medium was changed every other day and experiments were performed 21 days post-seeding on fully differentiated, confluent monolayers with mucus secretion verified using Alcian blue (stains acid mucopolysaccharides) and periodic acid Schiff (stains hexose and sialic acid-containing mucosubstances). After full differentiation the medium was exchanged to antibiotic free medium for $24 \mathrm{~h}$. Tested bacterial cultures were grown in CDLSIM medium and prepared as described above. Bacterial cultures were washed with sterile $0.85 \% \mathrm{NaCl}$, and resuspended in DMEM for application to the cell monolayers. Cell monolayers were carefully washed with $500 \mu \mathrm{L}$ of warm PBS. For all tests, bifidobacteria were added at $\log _{10} 7.7 \pm 0.12 \mathrm{CFU} / \mathrm{mL}$ and S. Typhi N15 and EHEC were added at approximately $\log _{10}$ $6.3 \pm 0.05 \mathrm{CFU} / \mathrm{mL}$ in DMEM to the HT29-MTX monolayer. After $2 \mathrm{~h}$ incubation at $37^{\circ} \mathrm{C}$, HT29-MTX monolayers were washed twice with PBS to remove non-attached bacteria and detached using $0.25 \%$ trypsin-EDTA solution (Life Technologies, Switzerland). Bacterial cell counts were determined as described above. Adhesion was expressed as the percent ratio of adhered bacteria to number of bacteria added to the HT29-MTX cells monolayer. Experiments were performed in triplicates on three consecutive passages of the HT29-MTX cell line.

To determine the inhibition of pathogen adhesion by bifidobacteria the method of Gagnon et al. (2013) was used with slight modifications. Briefly, bifidobacteria were applied to the cell monolayer for $1 \mathrm{~h}$. Then the well was washed once with PBS to remove non-adhering cells and the tested pathogen was added for a further incubation of $1 \mathrm{~h}$. Enumeration of adhered bacteria was performed after serial dilution on respective media. To examine if adhered pathogenic bacteria could be displaced by the addition of bifidobacteria, enteropathogens were incubated $1 \mathrm{~h}$ and, after PBS washing, bifidobacteria were added and incubated $1 \mathrm{~h}$. To investigate the ability of bifidobacteria to competitively exclude enteropathogens, bifidobacteria and pathogenic bacteria were added simultaneously to the HT29MTX monolayer and incubated for $2 \mathrm{~h}$. All incubations were done at $37^{\circ} \mathrm{C}$ and $10 \% \mathrm{CO}_{2}$. HT29-MTX monolayers were washed twice with PBS to remove non-attached bacteria, and treated with a $0.25 \%$ trypsin-EDTA solution for $15 \mathrm{~min}$, for bifidobacteria and enteropathogens enumeration as stated earlier. Activity of bifidobacteria strains to compete with, displace and inhibit the adhesion of $S$. Typhi N15 and EHEC to the intestinal epithelial cell line HT29-MTX was expressed by the adhesion ratio. This corresponded to the ratio of the percentage of adhered bifidobacteria or pathogenic bacteria following simultaneous addition divided by the percentage of adhesion of the bacteria added alone to the cell culture (Serafini et al., 2013). All the above tests were carried out in triplicates on three consecutive passages of the HT29-MTX cell line.

\section{Statistical Analysis}

To assess differences between treatments in inhibitory activity in mono- and co-culture experiments, and surface properties of bifidobacteria strains, the means of three independent repetitions were compared using un-paired Student's $t$-test. ANOVA with post hoc Tukey test was used to assess significant affinity of bifidobacteria and pathogens to ECM when compared to PBS control $(P$-value $<0.05)$. Significant differences in competition, inhibition and displacement experiments were tested by comparing the means of three independent repetition of the HT29-MTX cell line using un-paired Student's $t$-test. Statistical significance was established at $P$-value $<0.05$ and SPSS software 17.0 (SPSS, Inc., Chicago, IL, USA) was used.

\section{RESULTS}

\section{Inhibitory Activity of $B$. pseudolongum PV8-2 and B. kashiwanohense PV20-2 against Enteropathogens}

The inhibitory activities of Bp PV8-2 and Bk PV20-2 against $S$. Typhi N15 and EHEC were tested in co-culture experiments and compared to mono-cultures of the same strains (Figures 1 and 2). Mono-cultures of Bp PV8-2 reached maximum viable 


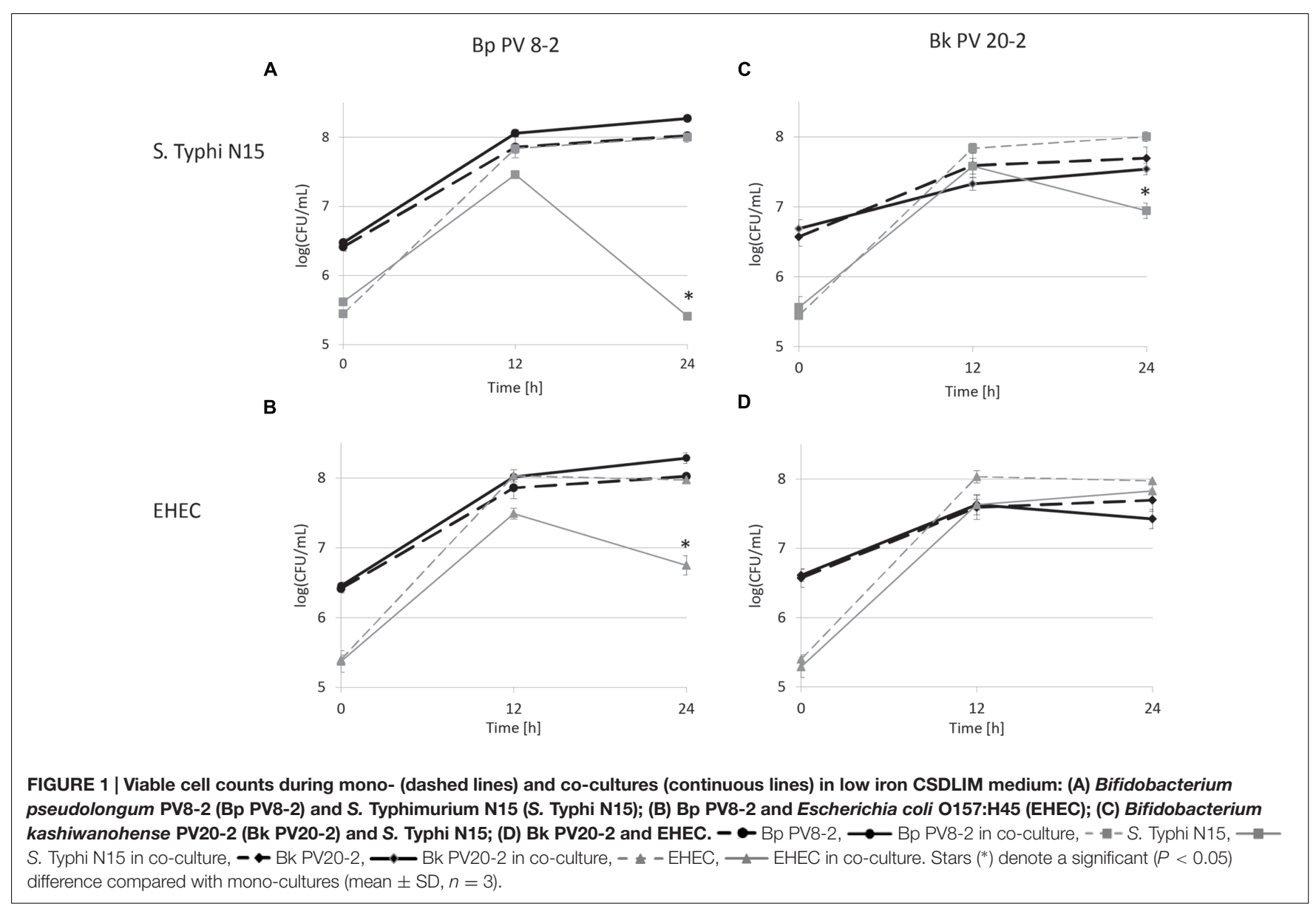

cell counts of $\log _{10} 8.1 \pm 0.1 \mathrm{CFU} / \mathrm{mL}$ with and without iron supplementation, and $\mathrm{pH}$ of $4.5 \pm 0.06$ and $4.2 \pm 0.01$ after $24 \mathrm{~h}$ incubation in CDSLIM medium, respectively. In decreasing concentration the main organic acids produced were acetate, lactate and formate (Table 1). Iron supplementation significantly $(P<0.05)$ increased production of all metabolites, by 12,17 , and $29 \%$ for acetate, lactate and formate, respectively, when compared to cultures in unsupplemented media. Similarly, Bk PV20-2 in mono-cultures reached viable cells counts of $\log _{10}$ $7.7 \pm 0.2 \mathrm{CFU} / \mathrm{mL}$ with and without iron, and $\mathrm{pH}$ was $5.3 \pm 0.04$ and $4.7 \pm 0.01$, respectively. Organic acid productions were also significantly $(P<0.05)$ increased with iron, by $27 \%$ for acetate and $20 \%$ for lactate. No significant effect of iron on growth or metabolite production was observed during monocultures of enteropathogens. EHEC reached cell counts of $\log _{10}$ $7.9 \pm 0.1 \mathrm{CFU} / \mathrm{mL}$ after $12 \mathrm{~h}$ and remained stable until $24 \mathrm{~h}$ of culture. pH after $24 \mathrm{~h}$ was $4.88 \pm 0.01$ and $5.05 \pm 0.02$, with and without iron supplementation, respectively. Main metabolites were lactate and acetate for S. Typhi N15 and EHEC (Table 1).

Viable cell counts of $S$. Typhi N15 significantly decreased $(P<0.05)$ by $\log _{10} 2.5 \pm 0.1 \mathrm{CFU} / \mathrm{mL}$ in co-culture with Bp PV8-2 and by $\log _{10} 1.1 \pm 0.1 \mathrm{CFU} / \mathrm{mL}$ with Bk PV20-2 after $24 \mathrm{~h}$ when compared with mono-cultures of $S$. Typhi $\mathrm{N} 15$ (Figures 1A,C). pH after $24 \mathrm{~h}$ of co-cultures of $S$.
Typhi N15 with Bp PV8-2 was $4.19 \pm 0.02$ and $4.21 \pm 0.02$ and with Bk PV20-2 $4.62 \pm 0.01$ and $4.59 \pm 0.01$, with or without iron supplementation, respectively. EHEC counts significantly decreased after $12 \mathrm{~h}$ when co-cultured with $\mathrm{Bp}$ PV8-2 compare to monocultures (Figure 1B). No significant differences were observed when co-culturing EHEC with Bk PV20-2. Metabolites produced during co-cultures of $S$. Typhi N15 and EHEC with Bp PV8-2 were in decreasing order acetate, lactate and formate (Table 1), whereas with Bk PV202 only acetate and lactate were identified (Tables 1 and 2). No significant differences in metabolites were observed following iron supplementation of the media. No significant effect of iron supplementation was detected on EHEC growth during co-cultures (Figures 1 and 2).

Salmonella Typhi and EHEC were tested for the inhibitory conditions observed after $12 \mathrm{~h}$ of co-culture with bifidobacterial strains. CDSLIM medium was supplemented with $13 \mathrm{mM}$ of acetate and $7 \mathrm{mM}$ of lactate at $\mathrm{pH} 4.5$ and growth tested for $24 \mathrm{~h}$. S. Typhi N15 and EHEC viable cell counts remained constant $\left(\log _{10} 5.4 \pm 0.12 \mathrm{CFU} / \mathrm{mL}\right)$ during $24 \mathrm{~h}$. In contrast a significant viability decrease of $S$. Typhi N15 (Bp PV8-2 and Bk PV20-2) and EHEC (Bp PV8-2) was measured during co-cultures with both bifidobacteria between 12 and $24 \mathrm{~h}$ for both iron levels (Figures 1A-C and $2 \mathrm{~A}-\mathrm{C}$ ). 
A

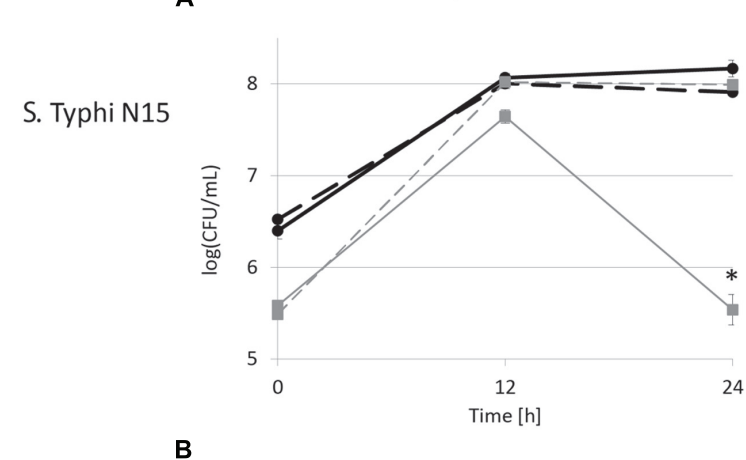

B

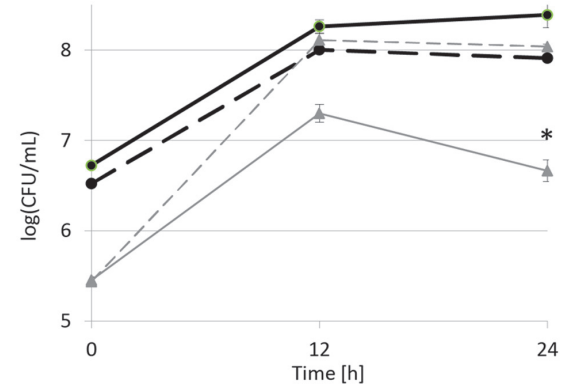

C

Bk PV 20-2

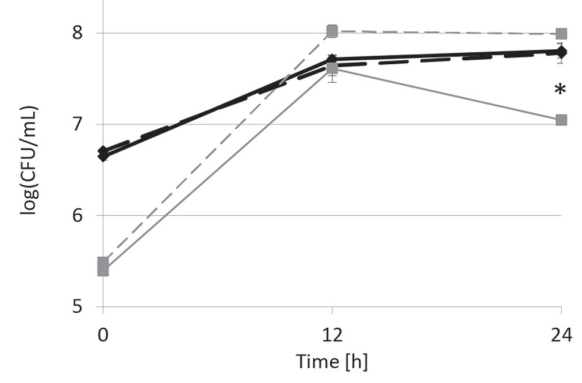

D

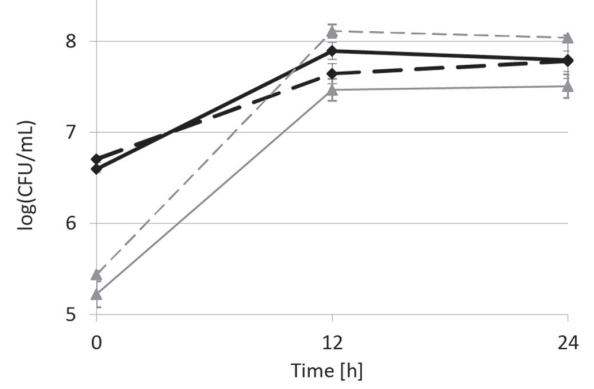

FIGURE 2 | Viable cell counts during co-cultures in iron supplemented (30 $\mu \mathrm{M})$ CSDLIM medium: (A) B. pseudolongum PV8-2 (Bp PV8-2) and S. Typhimurium N15 (S. Typhi N15); (B) Bp PV8-2 and E. coli 0157:H45 (EHEC); (C) B. kashiwanohense PV20-2 (Bk PV20-2) and S. Typhi N15; (D) Bk

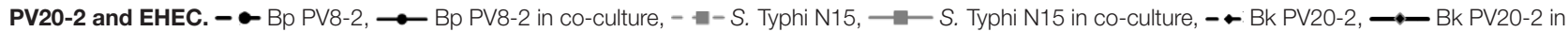
co-culture, - $\neq-$ EHEC, —- EHEC in co-culture. Stars $\left({ }^{*}\right)$ denote a significant $(P<0.05)$ difference compared with mono-cultures (mean $\left.\pm \mathrm{SD}, n=3\right)$.

TABLE 1 | pH and concentrations of metabolites $(\mathrm{mM})$ in culture supernatant measured with HPLC after $24 \mathrm{~h}$ incubation of mono- and co-cultures of Bifidobacterium pseudolongum PV8-2 in CSDLIM media (mean \pm SD, $n=3$ ).

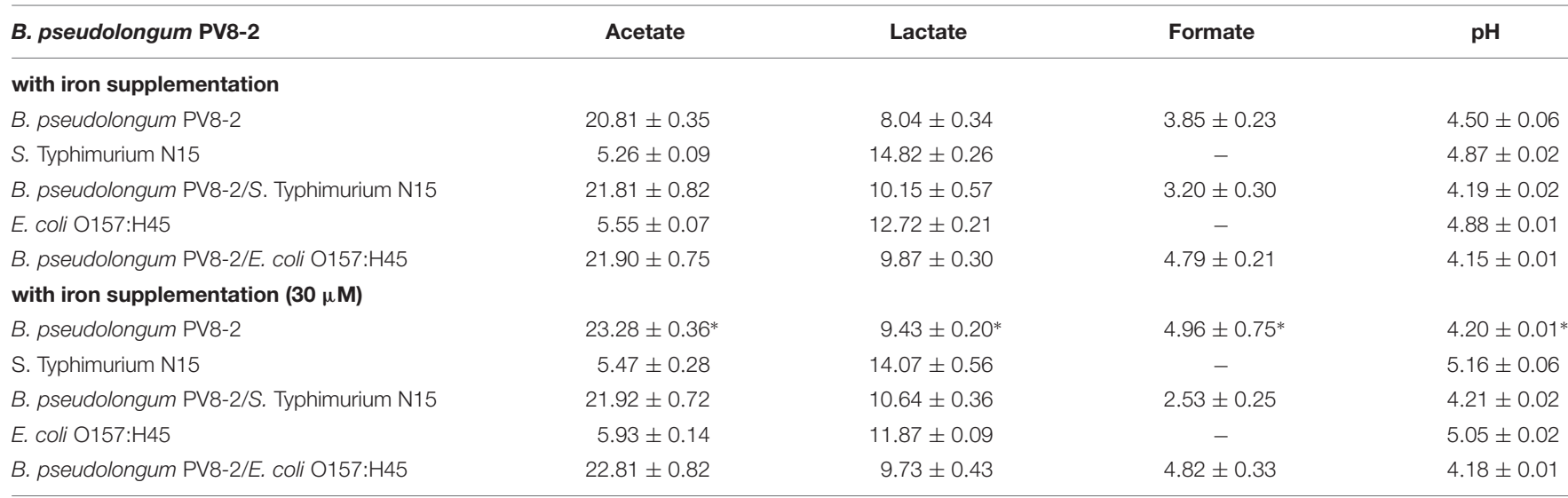

Stars $\left.{ }^{*}\right)$ denote a significant $(P<0.05)$ difference in the respective metabolite production of cultures performed in iron supplemented compared with unsupplemented medium.

\section{Surface Properties of Bifidobacteria Strains}

Physico-chemical characteristics of bifidobacteria cell surfaces, such as hydrophobicity, electron-donor and electron-acceptor properties, are related to adhesion to intestinal epithelial cells. The affinity of bifidobacteria strains to different solvents, xylene, chloroform and ethyl-acetate, was determined using the BATS assay to quantify surface hydrophobicity. Bp PV8-2 showed similar surface properties as the type strain DSMZ20099 (Figure 3). Under iron-limited conditions affinity to hydrophobic xylene was $84.4 \pm 3.6 \%$ for Bp PV8-2 and $88.3 \pm 11.6 \%$ for Bp DSMZ20099. Affinity to chloroform, an acidic solvent, was $99.2 \pm 1 \%$ for Bp PV8-2 and $98.4 \pm 3.5 \%$ for Bp DSMZ20099. No hydrophobic, electron donor/acceptor properties were observed for Bk PV20-2 (Figure 3B), whereas Bk DSMZ21854 showed hydrophobic and electron-donor properties only when grown 
TABLE 2 | pH and concentrations of metabolites ( $\mathrm{mM}$ ) in culture supernatant measured with HPLC after $24 \mathrm{~h}$ incubation of mono- and co-cultures of Bifidobacterium kashiwanohense PV20-2 in CSDLIM media (mean $\pm \mathrm{SD}, \boldsymbol{n}=3$ ).

\begin{tabular}{|c|c|c|c|}
\hline $\begin{array}{l}\text { B. kashiwanohense } \\
\text { PV20-2 }\end{array}$ & Acetate & Lactate & pH \\
\hline \multicolumn{4}{|c|}{ without iron supplementation } \\
\hline B. kashiwanohense PV2O-2 & $8.69 \pm 0.55$ & $5.08 \pm 0.20$ & $5.30 \pm 0.04$ \\
\hline S. Typhimurium N15 & $5.26 \pm 0.09$ & $14.82 \pm 0.26$ & $4.87 \pm 0.02$ \\
\hline $\begin{array}{l}\text { B. kashiwanohense } \\
\text { PV20-2/S. Typhimurium } \\
\text { N15 }\end{array}$ & $10.18 \pm 0.40$ & $10.04 \pm 0.29$ & $4.62 \pm 0.01$ \\
\hline E. coli O157:H45 & $5.55 \pm 0.07$ & $12.72 \pm 0.21$ & $4.88 \pm 0.01$ \\
\hline $\begin{array}{l}\text { B. kashiwanohense } \\
\text { PV20-2/E. coli O157:H45 }\end{array}$ & $9.55 \pm 0.29$ & $9.18 \pm 0.28$ & $4.64 \pm 0.01$ \\
\hline \multicolumn{4}{|c|}{ with iron supplementation (30 $\mu \mathrm{M})$} \\
\hline B. kashiwanohense PV20-2 & $11.00 \pm 0.09 *$ & $6.08 \pm 0.06^{*}$ & $4.70 \pm 0.01$ \\
\hline S. Typhimurium N15 & $5.47 \pm 0.28$ & $14.07 \pm 0.56$ & $5.16 \pm 0.06$ \\
\hline $\begin{array}{l}\text { B. kashiwanohense } \\
\text { PV20-2/S. Typhimurium } \\
\text { N15 }\end{array}$ & $12.67 \pm 0.34^{*}$ & $8.63 \pm 0.17^{*}$ & $4.59 \pm 0.01$ \\
\hline E. coli O157: $\mathrm{H} 45$ & $5.93 \pm 0.14$ & $11.87 \pm 0.09$ & $5.05 \pm 0.02$ \\
\hline $\begin{array}{l}\text { B. kashiwanohense } \\
\text { PV20-2/E. coli O157:H45 }\end{array}$ & $12.29 \pm 0.16^{*}$ & $8.02 \pm 0.27^{*}$ & $4.61 \pm 0.01$ \\
\hline
\end{tabular}

Stars $\left(^{*}\right)$ denote a significant $(P<0.05)$ difference in the respective metabolite production of cultures performed in iron supplemented compared with unsupplemented medium.

in CDSLIM (Figure 3D). Electron-acceptor properties were not observed for any of the strains tested. Bifidobacteria strains showed less affinity to all solvents when grown in MRS-cys compared to CDSLIM.

\section{Adhesion to Different Intestinal Cell Surface Molecules}

The intestinal epithelial cell surface is covered by glycoproteins, such as type II mucus, collagen, fibrinogen and fibronectin, and can serve as attachment sites for microbes. The affinity of bacteria to glycoproteins can therefore influence strain capacity to compete for epithelial binding sites. No significant adhesion to the unspecific protein binding control BSA nor to collagen I was shown for the tested strains when compared with the uncoated control wells (Figures 4A,B). Bp PV8-2, showed significant $(P<0.05)$ adhesion at $\mathrm{pH} 5.5$ to type II mucin and Bk PV20-2 and Bk DSMZ21854 to fibronectin when compared with the uncoated control (Figure 4A). S. Typhi N15 showed significant $(P<0.05)$ adhesion to type II mucin, fibronectin, and fibrinogen. EHEC bound to type II mucin and fibronectin when compared with the uncoated control. At pH 7.5, all strains showed similar affinity to glycoproteins, BSA and the uncoated control (Figure 4B), except $S$. Typhi N15 that showed significantly $(P<0.05)$ higher adhesion to mucin II, fibrinogen, and fibronectin.

\section{In vitro Inhibition of Bifidobacteria Strains against $S$. Typhimurium N15 and EHEC}

The ability to adhere to mucus and epithelial cells is an important feature for the barrier effect of bifidobacteria. The adhesion ratios of Bk PV20-2 and Bk DSMZ21854 to mucussecreting HT29-MTX were significantly higher (15.6 $\pm 6.0 \%$ and $12.7 \pm 2.4 \%$, respectively) when compared to both Bp PV8-2 and Bp DSMZ20099 (1.4 $\pm 0.4 \%$ and $1.3 \pm 0.3 \%$, respectively). Very high adhesion ratios of $S$. Typhi N15 and EHEC were measured, with $87.8 \pm 17.5 \%$ and $137.6 \pm 51.7 \%$, respectively, likely reflecting growth of the enteropathogens during the test.

The ability of bifidobacteria strains, to compete, displace and inhibit the adhesion of enteropathogens was tested on the HT29-MTX epithelial cell model. Both strains exhibited competitive abilities when added together with $S$. Typhi N15 in the competition assay, as shown by adhesion ratios significantly higher than 1 (1.88 \pm 0.64 for Bp PV8-2 and $1.76 \pm 0.51$ for Bk PV20-2; Figures 5A,B). In contrast, adhesion ratios lower than $1(P<0.05)$ were measured for $S$. Typhi N15 in competition with Bp PV8-2 (0.67 \pm 0.08$)$ and Bk PV20-2 (0.80 \pm 0.22$)$, indicating that enteropathogen adhesion was decreased in the presence of both bifidobacteria. In the displacement assay, Bp PV8-2 and Bk PV20-2 strains induced the release of S. Typhi N15 bound to HT29-MTX, indicated by adhesion ratios of $0.43 \pm 0.15$ and $0.44 \pm 0.13$, respectively. The inhibition assay showed that adhered bifidobacteria prevented the attachment of S. Typhi N15 and stably occupied a sufficient number of adhesion sites on the surface of HT29-MTX cells. Bp PV8-2 showed the highest degree of inhibition of $S$. Typhi N15 $(0.08 \pm 0.04)$ compared to Bk PV20-2 (0.21 \pm 0.12$)$.

Bk PV20-2 was not able to competitively exclude EHEC in the competition assay, as indicated in Figure 5D. In the displacement assay with EHEC added first, Bp PV8-2 showed low adhesion ratio of $0.16 \pm 0.03$ compared with $0.51 \pm 0.31$ for EHEC which was not significantly different from 1 (Figure 5C). This data suggest that Bp PV8-2 could not displace previously adhered EHEC. In the inhibition assay (Figure 5D), EHEC adhesion could be significantly $(P<0.05)$ decreased by the presence of adhered Bp PV8-2. Bk PV20-2 did not reduce adhesion of EHEC when added simultaneously (competition assay) or after the addition of EHEC (displacement assay).

\section{DISCUSSION}

\section{Inhibitory Activity of $B$. pseudolongum PV8-2 and B. kashiwanohense PV20-2 against Enteropathogens}

Bifidobacteria play an essential role in the development and homeostasis of the host's immune system in infants where they represent one of the first commensal anaerobic bacteria colonizing the gut (Gupta and Garg, 2009). Efficient competition for iron is a key factor for bacterial growth, persistence and establishment in the intestine (Andrews et al., 2003). In our previous research, B. pseudolongum PV8-2 and B. kashiwanohense PV20-2 isolated from anemic infants in Kenya were therefore selected for this study based on their high iron sequestration capacity (Vazquez-Gutierrez et al., 2015c). Their inhibitory activities against two strains of enteropathogens, 
A B. pseudolongum PV20-2

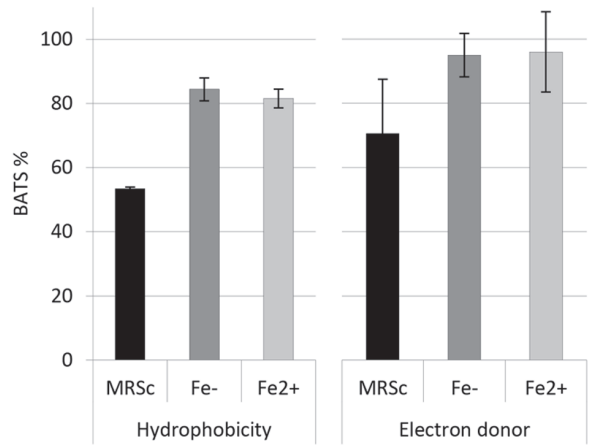

B

B. kashiwanohense PV20-2

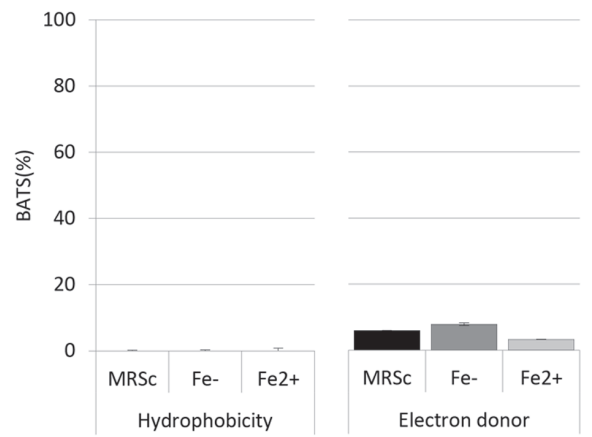

C

\section{B. pseudolongum DSMZ20099}
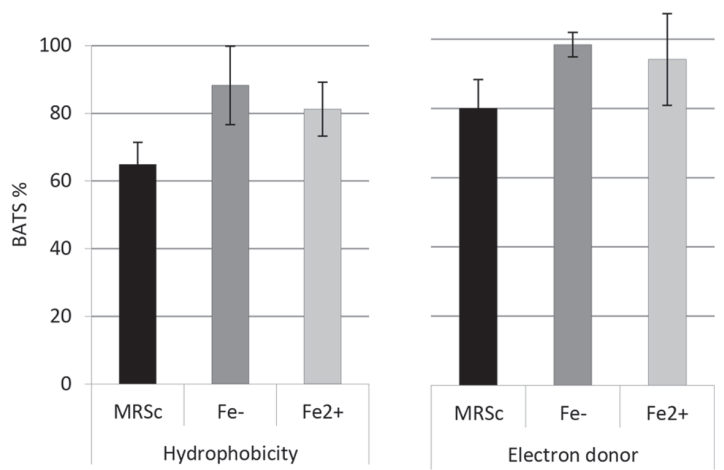

D

\section{B. kashiwanohense DSMZ21854}

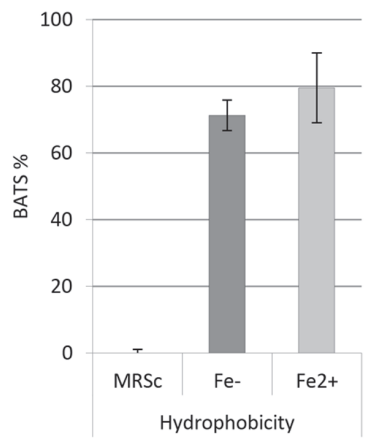

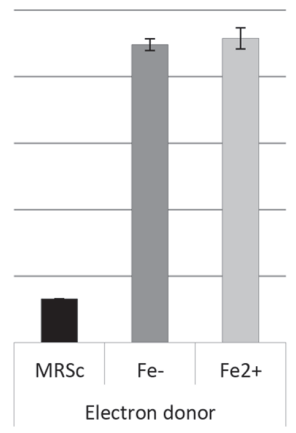

FIGURE 3 | Adhesion affinity of (A) B. pseudolongum PV8-2, (B) B. pseudolongum DSMZ20099, (C) B. kashiwanohense PV20-2, and (D) B. kashiwanohense DSMZ21854 to xylene (hydrophobicity) and chloroform (electron-donor properties). Bifidobacterial strains were grown in MRS-cys and in CSDLIM without and with iron supplementation (mean \pm SD, $n=3$ ). [Fe-: without iron supplementation (1.5 $\mu \mathrm{M})$, Fe ${ }^{2+}$ : with iron supplementation (30 $\left.\mu \mathrm{M}\right)$.]

S. Typhi N15 and E. coli O157:H45 which are known to efficiently bind iron, were tested in vitro. Bifidobacteria may exert inhibitory activity against enteropathogens by production of organic acids, competition for essential growth nutrients, production of antibacterial peptides and co-aggregation with pathogens (Turroni et al., 2009; Butel, 2014; Ventura et al., 2014). Organic acids can prevent infections of pathogens by lowering the intestinal $\mathrm{pH}$ and hence restricting colonization of pathogenic bacteria that are sensitive to low pH (Bernet et al., 1993; Lievin et al., 2000; Shu et al., 2000; Gopal et al., 2001; Shu and Gill, 2001; Hammami et al., 2013).

Co-cultivation experiments revealed the inhibitory effects of Bp PV8-2 and Bk PV20-2 against S. Typhi N15 and EHEC. Both enteropathogens were not affected by incubation at low $\mathrm{pH}$ and organic acid concentrations produced by the bifidobacteria strains during co-cultures. While growth of EHEC was inhibited by Bp PV8-2 and slightly reduced by Bk PV 20-2 (not significantly), S. Typhi N15 was significantly reduced by both bifidobacterial strains during co-cultures compared with single cultures. The reduction of viability of enteropathogens in co-cultures could be the result of different factors combined, such as the fitness of the strain under test conditions, and high iron sequestration mechanisms and the production of inhibitory substances by bifidobacteria (Bailey et al., 2011). Additionally, lactate and acetate, may also function as a permeabilizer of the outer membrane of Gram-negative bacteria and may thus accentuate the effects of other inhibitory substances, such as bacteriocins (Oh et al., 2009).

For example, the extracellular proteome of Bp PV8-2 showed the expression of a lysozyme that might contribute to the inhibitory activity of the strain (Vazquez-Gutierrez, 2014), and the effect might be increased by the production of organic acids (Tejero-Sarinena et al., 2012). Both Bifidobacterium strains tested were less efficient against EHEC, possibly because EHEC has the ability to survive in many adverse conditions when it enters starvation, allowing EHEC to adapt to very harsh conditions with almost no available nutrients, including iron (Chekabab et al., 2013).

\section{Adhesion and Competition at the Intestinal Epithelium}

The potential of Bp PV8-2 and Bk PV 20-2 to compete for adhesion sites was tested. Occupation of adhesion sites can reduce pathogen adhesion to intestinal epithelium and is mediated by bacterial surface properties like hydrophobicity and cell surface proteins (Botes et al., 2008; Xu et al., 2009). Bp PV8-2 had high affinity for the non-polar solvent xylene, indicating that this strain has hydrophobic cell surface properties. In contrast Bk PV20-2 


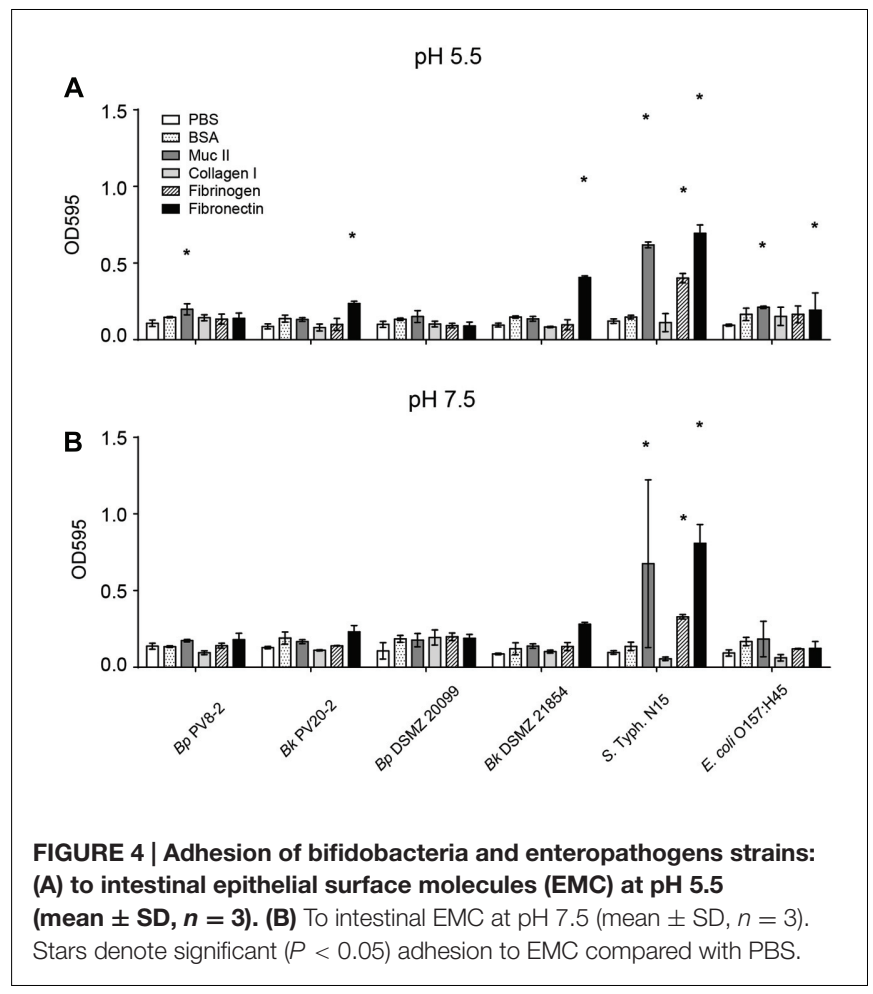

was hydrophilic and showed no acid-base properties. The growth medium of bifidobacteria had a strong effect on strain surface property, in contrast with iron availability which did not affect the surface characteristics. Affinity to solvents data indicated that
Bp PV8-2 has similar physico-chemical cell surface properties to type strain Bp DSMZ20099. In contrast, affinities to solvents of Bk PV20-2 and Bk DSMZ21854 were similar when both strains were grown in MRS-cys but very different when grown in CSDLIM, emphasizing the influence of growth conditions on surface properties of bacterial strains (Xu et al., 2009). Canzi et al. (2005) reported that even very close genetically related bifidobacteria strains can exhibit significantly different adhesion activities to hydrocarbons (xylene and hexadecane), supporting high strain specificity (Del Re et al., 2000).

Adhesion affinity to different binding sites of the intestinal epithelium was subsequently quantified by the adhesion affinity to a representative set of surface glycoproteins. Specific binding affinity to type II mucin was low for all strains, consistent with the findings of Collado et al. (2005) who observed weak adherence of bifidobacterial strains of human origin to human intestinal mucus glycoproteins. Bk PV20-2 and Bk DSMZ21854 showed affinity for fibronectin. Bk strains shared the binding affinity to fibronectin with both enteropathogens (Fujiwara et al., 2001), suggesting possible competition for intestinal binding sites by Bk PV20-2 that could prevent infections (Collado et al., 2005; Sperandio, 2012). Adhesion to extracellular glycoproteins of all strains was increased at $\mathrm{pH} 5.5$ compared with $\mathrm{pH}$ 7.5. The acid environment resulting from the colonization of bifidobacteria could further support the competition for the epithelial binding sites, emphasizing the importance of the combined effect of physico-chemical affinity and surface properties (de Wouters et al., 2015; Jans et al., 2016).

Competition between bifidobacteria strains and entero pathogens by competition, displacement and inhibition was
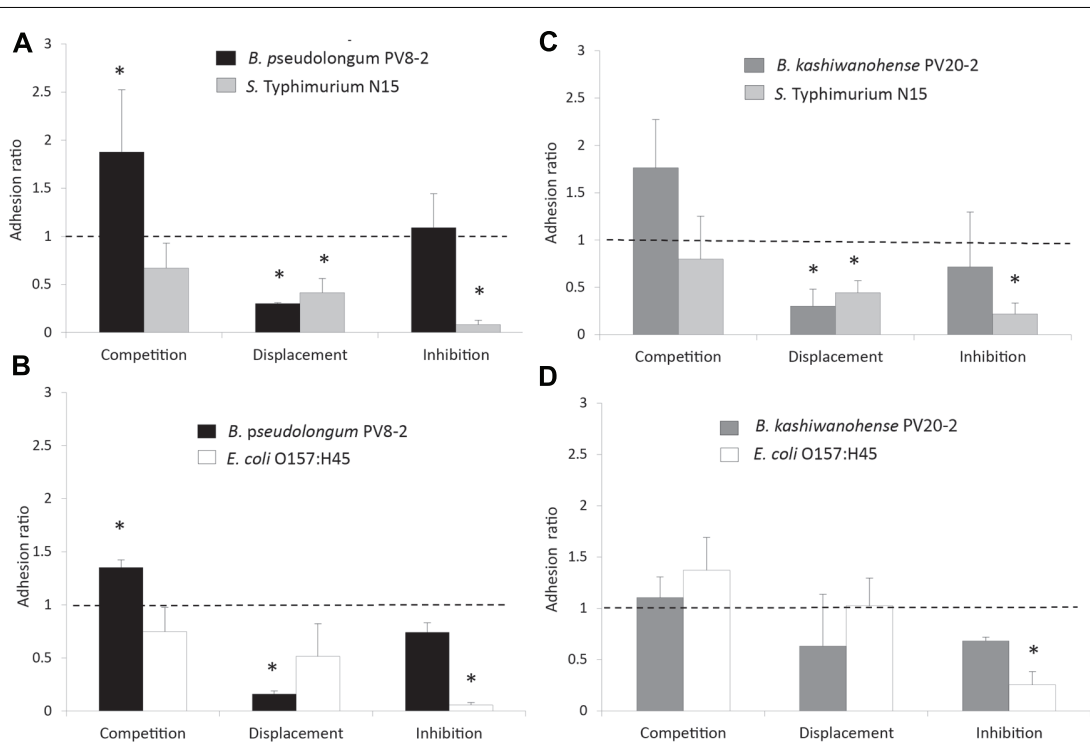

FIGURE 5 | Adhesion ratios of bifidobacteria and enteropathogens measured during competition, displacement and inhibition tests performed with mucus-producing HT29-MTX cell line: (A) B. pseudolongum PV8-2 (Bp PV8-2) and S. Typhimurium N15 (S. Typhi N15); (B) B. kashiwanohense PV20-2 (Bk PV20-2) and E. coli 0157:H45 (EHEC); (C) Bk PV20-2 and S. Typhi N15; (D) Bk PV20-2 and EHEC. The adhesion ratio corresponded to the ratio of the percentage of adhered bifidobacteria or pathogenic bacteria following simultaneous addition divided by the percentage of adhesion of the Bifidobacterium strain or pathogenic bacteria added alone to the cell culture. Dotted line (adhesion ratio $=1$ ) indicates no effect of interactions of tested cultures. Columns with a star $\left({ }^{\star}\right.$ ) indicate significantly different $(P<0.05)$ values when compared to 1 (mean $\pm \mathrm{SD}, n=3$ ). 
then studied on a differentiated, mucus-secreting HT29-MTX cells monolayer. In agreement with adhesion tests with single surface molecules, Bp strains showed only modest adhesion abilities to mucus-secreting HT29-MTX cells compared with Bk strains, S. Typhi N15 and EHEC. The high adhesion properties of both enteropathogens may reflect growth of the strain during the incubation test with cell layers as previously reported for Salmonella in a similar cell test (Dostal et al., 2014). Several studies suggest correlation between adhesion to intestinal cells and cell surface hydrophobicity measured with the BATS assay (Marin et al., 1997; Del Re et al., 2000), a result which was not confirmed in other studies (Savage, 1992; Ouwehand et al., 1999; Canzi et al., 2005; de Wouters et al., 2015). Even though hydrophobicity did not correlate with adhesion properties, BATS assay showed that cell surface properties of Bp PV8-2 and Bk PV20-2 are different, indicating strain-specificity. Bk PV20-2 strain showed no hydrophobic affinity suggesting that adhesion might be mediated by adhesion-like factors (Turroni et al., 2009; Ventura et al., 2014).

Adhesion properties of beneficial bifidobacteria to the mucosa have been shown to promote gut residence time, pathogen exclusion, protection of epithelial cells and immune modulation. Our data indicated that the degree of competition was dependent on bifidobacteria and enteropathogen strain. While both bifidobacteria strains were able to competitively exclude $S$. Typhi N15, only Bp PV8-2 was able to decrease the adhesion capacity of EHEC. In the presence of Bk PV20-2 adhesion of EHEC was increased, suggesting a sharing of metabolic activities leading to enhanced adhesion (Collado et al., 2005). Previous studies reported increased enteropathogen adhesion by bifidobacteria. For example under similar experimental conditions, Serafini et al. (2013) investigated antagonistic effects of Bifidobacterium bifidum PRL2010 against various enteropathogens, including $S$. Typhi and EHEC on HT-29 cells not secreting mucus (Gueimonde et al., 2006; Serafini et al., 2013). Our data suggests a direct competition for binding sites that protect the host against invasion of enteropathogens which might also be influenced by strain fitness related to iron sequestration mechanisms

\section{REFERENCES}

Aires, J., Anglade, P., Baraige, F., Zagorec, M., Champomier-Verges, M. C., and Butel, M. J. (2010). Proteomic comparison of the cytosolic proteins of three Bifidobacterium longum human isolates and B. longum NCC2705. BMC Microbiol. 10:29. doi: 10.1186/1471-2180-10-29

Andrews, S. C., Robinson, A. K., and Rodriguez-Quinones, F. (2003). Bacterial iron homeostasis. FEMS Microbiol. Rev. 27, 215-237. doi: 10.1016/S01686445(03)00055-X

Bailey, J. R., Probert, C. S., and Cogan, T. A. (2011). Identification and characterisation of an iron-responsive candidate probiotic. PLoS ONE 6:e26507. doi: 10.1371/journal.pone.0026507

Berkley, J. A., Lowe, B. S., Mwangi, I., Williams, T., Bauni, E., Mwarumba, S., et al. (2005). Bacteremia among children admitted to a rural hospital in Kenya. N. Engl. J. Med. 352, 39-47. doi: 10.1056/Nejmoa040275

Bernet, M. F., Brassart, D., Neeser, J. R., and Servin, A. L. (1993). Adhesion of human bifidobacterial strains to cultured human intestinal epithelial-cells and inhibition of enteropathogen-cell interactions. Appl. Environ. Microbiol. 59, 4121-4128.
(Chauviere et al., 1992; Lee and Puong, 2002). Both Bp PV8-2 and Bk PV20-2 resulted in marked reductions in adhesion of $S$. Typhi N15 and EHEC, indicating that colonization with these potential probiotic candidates selected for high iron sequestration mechanisms might offer at least partial protection from infection with enteropathogenic bacteria (Collado et al., 2007). Further experiments have to be performed in vivo to support these effects.

\section{CONCLUSION}

Ability of commensals such as bifidobacteria to restrain pathogen growth in the intestine is strongly affected by niche and nutrient competition. Our study showed that B. pseudolongum PV8-2 and B. kashiwanohense PV20-2, selected for their high iron sequestration mechanisms, exhibited strain-dependent inhibitory activity against $S$. Typhi N15 and EHEC. These strains may be potential probiotic candidates especially for inhibiting irondependent enteric pathogens such as enterobacteriaceae in the gut. The biological significance of such competitive probiotics and their potential as preventive or curative probiotics should be further investigated in vitro in presence of complex gut microbiota and in vivo with animal models.

\section{AUTHOR CONTRIBUTIONS}

PV-G, TW, CC, and CL designed the experiment. PV-G, JW performed and analyzed the experiments. TW, CC, and CL supervised the experiments. PV-G, JW, TW, CC, and CL wrote the manuscript. All authors read and approved the final manuscript.

\section{ACKNOWLEDGMENT}

This research was supported by own resources at ETH Zurich, Zurich Switzerland.

Bernet, M. F., Brassart, D., Neeser, J. R., and Servin, A. L. (1994). Lactobacillus acidophilus LA 1 binds to cultured human intestinal cell lines and inhibits cell attachment and cell invasion by enterovirulent bacteria. Gut 35, 483-489. doi: 10.1136/gut.35.4.483

Botes, M., Loos, B., van, Reenen CA, Dicks, L. M., and Dicks, L. M. (2008). Adhesion of the probiotic strains Enterococcus mundtii ST4SA and Lactobacillus plantarum 423 to Caco- 2 cells under conditions simulating the intestinal tract, and in the presence of antibiotics and anti-inflammatory medicaments. Arch. Microbiol. 190, 573-584. doi: 10.1007/s00203-008-0408-0

Broekaert, I. J., and Walker, W. A. (2006). Probiotics and chronic disease. J. Clin. Gastroenterol. 40, 270-274. doi: 10.1097/00004836-200603000-00021

Bron, P. A., van Baarlen, P., and Kleerebezem, M. (2012). Emerging molecular insights into the interaction between probiotics and the host intestinal mucosa. Nat. Rev. Microbiol. 10, 66-78. doi: 10.1038/nrmicro2690

Butel, M. J. (2014). Probiotics, gut microbiota and health. Med. Mal. Infect. 44, 1-8. doi: 10.1016/j.medmal.2013.10.002

Canzi, E., Guglielmetti, S., Mora, D., Tamagnini, I., and Parini, C. (2005). Conditions affecting cell surface properties of human intestinal bifidobacteria. Antonie Van Leeuwenhoek. 88(3-4), 207-219. doi: 10.1007/s10482-005-6501-3 
Cassat, J. E., and Skaar, E. P. (2013). Iron in infection and immunity. Cell Host Microb. 13, 509-519. doi: 10.1016/j.chom.2013.04.010

Cernat, R. C., and Scott, K. P. (2012). Evaluation of novel assays to assess the influence of different iron sources on the growth of Clostridium difficile. Anaerobe 18, 298-304. doi: 10.1016/j.anaerobe.2012.04.007

Chauviere, G., Coconnier, M. H., Kerneis, S., Darfeuille-Michaud, A., Joly, B., and Servin, A. L. (1992). Competitive exclusion of diarrheagenic Escherichia coli (ETEC) from human enterocyte-like Caco-2 cells by heat-killed Lactobacillus. FEMS Microbiol. Lett. 70, 213-217. doi: 10.1016/0378-1097(92) 90700-X

Cheikhyoussef, A., Pogori, N., Chen, W., and Zhang, H. (2008). Antimicrobial proteinaceous compounds obtained from bifidobacteria: from production to their application. In. J. Food Microbiol. 125, 215-222. doi: 10.1016/j.ijfoodmicro.2008.03.012

Chekabab, S. M., Paquin-Veillette, J., Dozois, C. M., and Harel, J. (2013). The ecological habitat and transmission of Escherichia coli O157:H7. FEMS Microbiol. Lett. 341, 1-12. doi: 10.1111/1574-6968.12078

Cleusix, V., Lacroix, C., Vollenweider, S., and Le Blay, G. (2008). Glycerol induces reuterin production and decreases Escherichia coli population in an in vitro model of colonic fermentation with immobilized human feces. FEMS Microbiol. Ecol. 63, 56-64. doi: 10.1111/j.1574-6941.2007.00412.x

Collado, M. C., Gueimonde, M., Hernandez, M., Sanz, Y., and Salminen, S. (2005). Adhesion of selected Bifidobacterium strains to human intestinal mucus and the role of adhesion in enteropathogen exclusion. J. Food Prot. 68, 2672-2678.

Collado, M. C., Meriluoto, J., and Salminen, S. (2007). Role of commercial probiotic strains against human pathogen adhesion to intestinal mucus. Lett. Appl. Microbiol. 45, 454-460. doi: 10.1111/j.1472-765X.2007.02212.x

de Wouters, T., Jans, C., Niederberger, T., Fischer, P., and Ruhs, P. A. (2015). Adhesion potential of intestinal microbes predicted by physicochemical characterization methods. PLoS ONE 10:e0136437. doi: 10.1371/journal.pone. 0136437

Del Re, B., Sgorbati, B., Miglioli, M., and Palenzona, D. (2000). Adhesion, autoaggregation and hydrophobicity of 13 strains of Bifidobacterium longum. Lett. Appl. Microbiol. 31, 438-442. doi: 10.1046/j.1365-2672.2000.00845.x

Dobson, A., Cotter, P. D., Ross, R. P., and Hill, C. (2012). Bacteriocin production: a probiotic trait? Appl. Environ. Microbiol. 78, 1-6. doi: 10.1128/AEM.05576-11

Dostal, A., Gagnon, M., Chassard, C., Zimmermann, M. B., O’Mahony, L., Lacroix, C., et al. (2014). Salmonella adhesion, invasion and cellular immune responses are differentially affected by iron concentrations in a combined in vitro gut fermentation-cell model. PLOS ONE 9:e93549. doi: 10.1371/journal.pone.0093549

Fujiwara, S., Hashiba, H., Hirota, T., and Forstner, J. F. (2001). Inhibition of the binding of enterotoxigenic Escherichia coli Pb176 to human intestinal epithelial cell line HCT-8 by an extracellular protein fraction containing BIF of Bifidobacterium longum SBT2928: suggestive evidence of blocking of the binding receptor gangliotetraosylceramide on the cell surface. Int. . J. Food Microbiol. 67, 97-106.

Fukuda, S., Toh, H., Hase, K., Oshima, K., Nakanishi, Y., Yoshimura, K., et al. (2011). Bifidobacteria can protect from enteropathogenic infection through production of acetate. Nature 469, 543-547. doi: 10.1038/Nature09646

Gagnon, M., Zihler Berner, A., Chervet, N., Chassard, C., and Lacroix, C. (2013). Comparison of the Caco-2, HT-29 and the mucus-secreting HT29MTX intestinal cell models to investigate Salmonella adhesion and invasion. J. Microbiol. Methods 94, 274-279. doi: 10.1016/j.mimet.2013.06.027

Gopal, P. K., Prasad, J., Smart, J., and Gill, H. S. (2001). In vitro adherence properties of Lactobacillus rhamnosus DR20 and Bifidobacterium lactis DR10 strains and their antagonistic activity against an enterotoxigenic Escherichia coli. Int. J. Food Microbiol. 67, 207-216. doi: 10.1016/S0168-1605(01)00440-8

Goto, Y., and Kiyono, H. (2012). Epithelial barrier: an interface for the crosscommunication between gut flora and immune system. Immunol. Rev. 245, 147-163. doi: 10.1111/j.1600-065X.2011.01078.x

Gueimonde, M., Jalonen, L., He, F., Hiramatsu, M., and Salminen, S. (2006). Adhesion and competitive inhibition and displacement of human enteropathogens by selected lactobacilli. Food Res. Int. 39, 467-471. doi: 10.1016/j.foodres.2005.10.003

Gupta, V., and Garg, R. (2009). Probiotics. Indian J. Med. Microbiol. 27, 202-209. doi: $10.4103 / 0255-0857.53201$
Hammami, R., Fernandez, B., Lacroix, C., and Fliss, I. (2013). Anti-infective properties of bacteriocins: an update. Cell. Mol. Life Sci. 70, 2947-2967. doi: 10.1007/s00018-012-1202-3

Haraga, A., Ohlson, M. B., and Miller, S. I. (2008). Salmonellae interplay with host cells. Nat. Rev. Microbiol. 6, 53-66. doi: 10.1038/nrmicro1788

Izquierdo, E., Medina, M., Ennahar, S., Marchioni, E., and Sanz, Y. (2008). Resistance to simulated gastrointestinal conditions and adhesion to mucus as probiotic criteria for Bifidobacterium longum strains. Curr. Microbiol. 56, 613-618. doi: 10.1007/s00284-008-9135-7

Jans, C., de Wouters, T., Bonfoh, B., Lacroix, C., Kaindi, D. W. M., Anderegg, J., et al. (2016). Phylogenetic, epidemiological and functional analyses of the Streptococcus bovis/Streptococcus equinus complex through an overarching MLST scheme. BMC Microbiol. 16:117. doi: 10.1186/s12866-016-0735-2

Jost, T., Lacroix, C., Braegger, C. P., and Chassard, C. (2012). New insights in gut microbiota establishment in healthy breast fed neonates. PLoS ONE 7:e44595. doi: 10.1371/journal.pone.0044595

Kortman, G. A., Boleij, A., Swinkels, D. W., and Tjalsma, H. (2012). Iron availability increases the pathogenic potential of Salmonella typhimurium and other enteric pathogens at the intestinal epithelial interface. PLOS ONE 7:e29968. doi: 10.1371/journal.pone.0029968

Lee, Y. K., and Puong, K. Y. (2002). Competition for adhesion between probiotics and human gastrointestinal pathogens in the presence of carbohydrate. $B r . J$. Nutr. 88(Suppl. 1), S101-S108. doi: 10.1079/BJN2002635

Lesuffleur, T., Barbat, A., Dussaulx, E., and Zweibaum, A. (1990). Growth adaptation to methotrexate of HT-29 human colon carcinoma cells is associated with their ability to differentiate into columnar absorptive and mucus-secreting cells. Cancer Res. 50, 6334-6343.

Lievin, V., Peiffer, I., Hudault, S., Rochat, F., Brassart, D., Neeser, J. R., et al. (2000). Bifidobacterium strains from resident infant human gastrointestinal microflora exert antimicrobial activity. Gut 47, 646-652. doi: 10.1136/gut.47.5.646

Marco, M. L., Pavan, S., and Kleerebezem, M. (2006). Towards understanding molecular modes of probiotic action. Curr. Opin. Biotechnol. 17, 204-210. doi: 10.1016/j.copbio.2006.02.005

Marin, M. L., Benito, Y., Pin, C., Fernandez, M. F., Garcia, M. L., Selgas, M. D., et al. (1997). Lactic acid bacteria: hydrophobicity and strength of attachment to meat surfaces. Lett. Appl. Microbiol. 24, 14-18. doi: 10.1046/j.1472765X.1997.00334.x

Martinez, F. A., Balciunas, E. M., Converti, A., Cotter, P. D., and de Souza Oliveira, R. P. (2013). Bacteriocin production by Bifidobacterium spp. A review. Biotechnol. Adv. 31, 482-488. doi: 10.1016/j.biotechadv.2013.01.010

Melton-Celsa, A., Mohawk, K., Teel, L., and O'Brien, A. (2012). Pathogenesis of Shiga-toxin producing Escherichia coli. Curr. Top. Microbiol. Immunol. 357, 67-103. doi: 10.1007/82_2011_176

Monack, D. M., and Hultgren, S. J. (2013). The complex interactions of bacterial pathogens and host defenses. Curr. Opin. Microbiol. 16, 1-3. doi: 10.1016/j.mib.2013.03.001

Muller, D., Benz, I., Liebchen, A., Gallitz, I., Karch, H., and Schmidt, M. A. (2009). Comparative analysis of the locus of enterocyte effacement and its flanking regions. Infect. Immun. 77, 3501-3513. doi: 10.1128/IAI.00090-09

Oh, D. H., Pan, Y. W., Berry, E., Cooley, M., Mandrell, R., and Breidt, F. (2009). Escherichia coli O157:H7 Strains isolated from environmental sources differ significantly in acetic acid resistance compared with human outbreak strains. J. Food Prot. 72, 503-509.

Ouwehand, A. C., Kirjavainen, P. V., Gronlund, M. M., Isolauri, E., and Salminen, S. J. (1999). Adhesion of probiotic micro-organisms to intestinal mucus. Int. Dairy J. 9, 623-630. doi: 10.1016/S0958-6946(99)00132-6

Sansonetti, P. J. (2004). War and peace at mucosal surfaces. Nat. Rev. Immunol. 4 , 953-964. doi: 10.1038/Nri1499

Santos, R. L., Raffatellu, M., Bevins, C. L., Adams, L. G., Tukel, C., Tsolis, R. M., et al. (2009). Life in the inflamed intestine, Salmonella style. Trends Microbiol. 17, 498-506. doi: 10.1016/j.tim.2009.08.008

Savage, D. C. (1992). Growth phase, cellular hydrophobicity, and adhesion in vitro of lactobacilli colonizing the keratinizing gastric epithelium in the mouse. Appl. Environ. Microbiol. 58, 1992-1995.

Serafini, F., Strati, F., Ruas-Madiedo, P., Turroni, F., Foroni, E., Duranti, S., et al. (2013). Evaluation of adhesion properties and antibacterial activities of the infant gut commensal Bifidobacterium bifidum PRL2010. Anaerobe 21, 9-17. doi: 10.1016/j.anaerobe.2013.03.003 
Shu, Q., and Gill, H. S. (2001). A dietary probiotic (Bifidobacterium lactis HN019) reduces the severity of Escherichia coli O157:H7 infection in mice. Med. Microbiol. Immunol. 189, 147-152. doi: 10.1007/s430-001-8021-9

Shu, Q., Lin, H., Rutherfurd, K. J., Fenwick, S. G., Prasad, J., Gopal, P. K., et al. (2000). Dietary Bifidobacterium lactis (HN019) enhances resistance to oral Salmonella Typhimurium infection in mice. Microbiol. Immunol. 44, 213-222. doi: $10.1111 / j .1348-0421.2000 . t b 02486 . x$

Sillanpaa, J., Nallapareddy, S. R., Singh, K. V., Ferraro, M. J., and Murray, B. E. (2008). Adherence characteristics of endocarditis-derived Streptococcus gallolyticus ssp. gallolyticus (Streptococcus bovis biotype I) isolates to host extracellular matrix proteins. FEMS Microbiol. Lett. 289, 104-109. doi: 10.1111/j.1574-6968.2008.01378.x

Sperandio, V. (2012). Microbiology. Virulence or competition? . Science 336, 1238-1239. doi: 10.1126/science. 1223303

Tejero-Sarinena, S., Barlow, J., Costabile, A., Gibson, G. R., and Rowland, I. (2012). In vitro evaluation of the antimicrobial activity of a range of probiotics against pathogens: evidence for the effects of organic acids. Anaerobe 18, 530-538. doi: 10.1016/j.anaerobe.2012.08.004

Thiennimitr, P., Winter, S. E., and Baumler, A. J. (2012). Salmonella, the host and its microbiota. Curr. Opin. Microbiol. 15, 108-114. doi: 10.1016/j.mib.2011. 10.002

Turroni, F., Marchesi, J. R., Foroni, E., Gueimonde, M., Shanahan, F., Margolles, A., et al. (2009). Microbiomic analysis of the bifidobacterial population in the human distal gut. ISME J. 3, 745-751. doi: 10.1038/ismej.2009.19

Turroni, F., Peano, C., Pass, D. A., Foroni, E., Severgnini, M., Claesson, M. J., et al. (2012). Diversity of bifidobacteria within the infant gut microbiota. PLoS ONE 7:e36957. doi: 10.1371/journal.pone.0036957

Turroni, F., Ventura, M., Butto, L. F., Duranti, S., O’Toole, P. W., Motherway, M. O., et al. (2014). Molecular dialogue between the human gut microbiota and the host: a Lactobacillus and Bifidobacterium perspective. Cell. Mol. Life Sci. 71, 183-203. doi: 10.1007/s00018-013-1318-0

Vazquez-Gutierrez, P. (2014). Screening and Characterization of Bifidobacteria with High Iron Binding Properties. Zürich: ETH-Zürich.

Vazquez-Gutierrez, P., Lacroix, C., Chassard, C., Klumpp, J., Jans, C., and Stevens, M. J. (2015a). Complete and assembled genome sequence of Bifidobacterium kashiwanohense PV20-2 isolated from the feces of an anemic Kenyan infant. Genome Announc. 3:e1467-14. doi: 10.1128/genomeA.01467-14
Vazquez-Gutierrez, P., Lacroix, C., Chassard, C., Klumpp, J., Stevens, M. J., and Jans, C. (2015b). Bifidobacterium pseudolongum strain PV8-2 isolated from a stool sample of an anemic Kenyan infant. Genome Announc. 3:e1469-14. doi: 10.1128/genomeA.01469-14

Vazquez-Gutierrez, P., Lacroix, C., Jaeggi, T., Zeder, C., Zimmerman, M. B., and Chassard, C. (2015c). Bifidobacteria strains isolated from stools of iron deficient infants can efficiently sequester iron. BMC Microbiol. 15:3. doi: 10.1186/s12866014-0334-z

Ventura, M., Turroni, F., Lugli, G. A., and van Sinderen, D. (2014). Bifidobacteria and humans: our special friends, from ecological to genomics perspectives. J. Sci. Food Agric. 94, 163-168. doi: 10.1002/jsfa.6356

Wardlaw, T., Salama, P., Brocklehurst, C., Chopra, M., and Mason, E. (2010). Diarrhoea: why children are still dying and what can be done. Lancet 375 , 870-872. doi: 10.1016/S0140-6736(09)61798-0

Weinberg, E. D. (2009). Iron availability and infection. Biochem. Biophys. Acta 1790, 600-605. doi: 10.1016/j.bbagen.2008.07.002

Winter, S. E., Lopez, C. A., and Baumler, A. J. (2013). The dynamics of gutassociated microbial communities during inflammation. EMBO Rep. 14, 319327. doi: 10.1038/embor.2013.27

Xu, H., Jeong, H. S., Lee, H. Y., and Ahn, J. (2009). Assessment of cell surface properties and adhesion potential of selected probiotic strains. Lett. Appl. Microbiol. 49, 434-442. doi: 10.1111/j.1472-765X.2009.02684.x

Yatsunenko, T., Rey, F. E., Manary, M. J., Trehan, I., Dominguez-Bello, M. G., Contreras, M., et al. (2012). Human gut microbiome viewed across age and geography. Nature 486, 222-227. doi: 10.1038/nature1 1053

Conflict of Interest Statement: The authors declare that the research was conducted in the absence of any commercial or financial relationships that could be construed as a potential conflict of interest.

Copyright () 2016 Vazquez-Gutierrez, de Wouters, Werder, Chassard and Lacroix. This is an open-access article distributed under the terms of the Creative Commons Attribution License (CC BY). The use, distribution or reproduction in other forums is permitted, provided the original author(s) or licensor are credited and that the original publication in this journal is cited, in accordance with accepted academic practice. No use, distribution or reproduction is permitted which does not comply with these terms. 